\title{
The scenario of development of electric power industry in the Republic of Kazakhstan
}

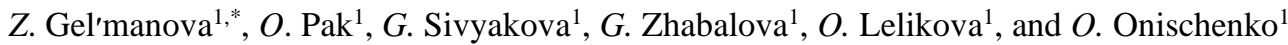 \\ ${ }^{1}$ Karaganda State Industrial University, Temirtau, Republic of Kazakhstan
}

\begin{abstract}
The article explored the energy sector of the Republic of Kazakhstan. The data on the demand for new installed capacity are presented. The scenarios for the development of the energy sector and factors determining the characteristics of scenarios are considered. The main results of the simulation are analyzed. SWOT analysis was made in the field of saving energy and efficiency energy. Based on the results of the data, conclusions were drawn and measures were proposed.
\end{abstract}

\section{Introduction}

The current state of the industry is characterized by significant deterioration of the generating and network equipment, the dominant position of coal generation, and lack of sufficient allowance to cover the peak load.

The development of the economy and implementation of energy efficiency measures will lead to increased energy consumption by $2.3 \%$ per year by 2030 (up to 136 billion $\mathrm{kW}(\mathrm{h})$ and $1.2 \%$ per year by 2050 (up to 172 billion $\mathrm{kWh}$ ). The energy intensity of Gross Domectic Product (GDP) will decrease by 50\% compared to 2010 [1]. Electricity demand up to 2050 is presented in figure 1 .

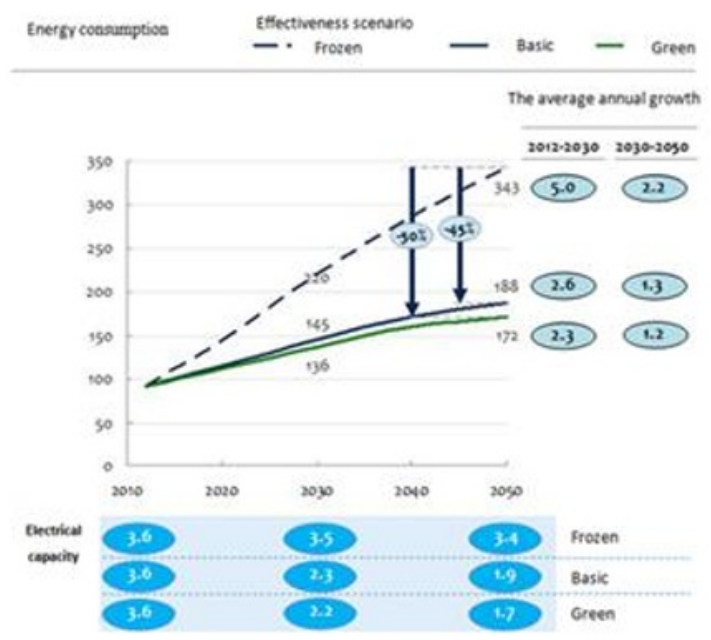

Fig. 1. Electricity demand up to $2050[2,3]$.

The growing demand for electricity and the decommissioning of old power plants because of the wear in Kazakhstan will require considerable construction of new capacities: 11-12 GW by 2030 (which corresponds to approximately $60 \%$ of the installed capacity in 2012) and 32-36 GW by 2050, not including installed capacity of renewable sources is unstable. Detailed data on the demand for new installed capacity is presented in figure 2 .

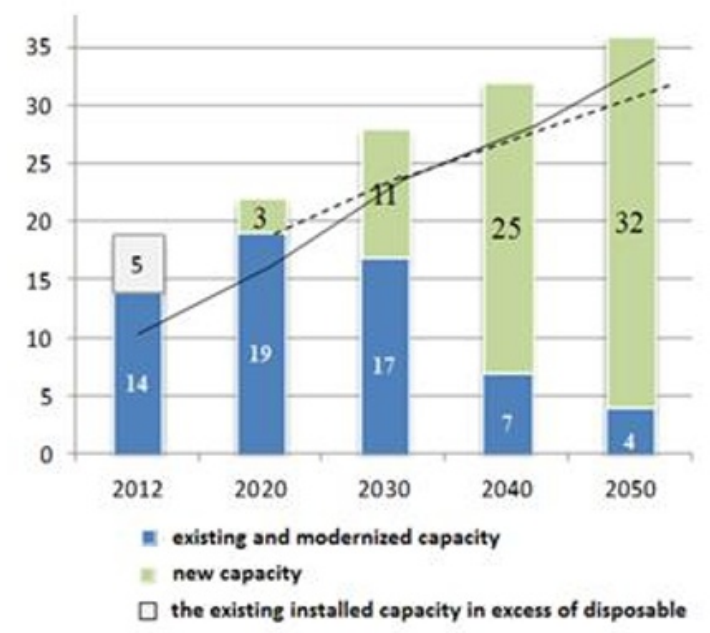

Fig. 2. The demand for new installed capacity [4].

\section{Methods}

There are several key factors that have a significant impact on the development of the energy sector of Kazakhstan.

There are three possible scenarios for the development of the energy sector. The factors that determine the characteristics of the scenarios $[5,6]$ :

- Reduction of electricity consumption through the adoption of measures to improve energy efficiency (including basic and "green" development scenarios of electricity demand, according to which the total demand for electricity will make $136-145$ billion $\mathrm{kWh}$ in 2030 and $186-206$ billion $\mathrm{kWh}$ in 2050 );

- The price of gas for the electricity (lower prices correspond to greater gas availability);

\footnotetext{
* Corresponding author: zoyakgiu@ mail.ru
} 
Table 1. Scenarios of development of power industry.

\begin{tabular}{|c|c|c|c|}
\hline \multirow[t]{2}{*}{ Factors } & \multicolumn{3}{|c|}{ Scenarios characteristics } \\
\hline & Basic & $\begin{array}{c}\text { «Green» } \\
\text { (expensive gas) }\end{array}$ & $\begin{array}{c}\text { «Green» } \\
\text { (cheap gas) }\end{array}$ \\
\hline Energy efficiency & $\begin{array}{l}\text { A decline of } 45 \% \text { relative to } \\
\text { the frozen scenario }\end{array}$ & \multicolumn{2}{|c|}{ A $50 \%$ reduction relative to the "frozen" scenario } \\
\hline The price of gas & The current gas low prices & $\begin{array}{l}\text { High: } \$ 300 \\
\text { US/thousand } \mathrm{m}^{3}\end{array}$ & Low: $\$ 150$ US/thousand $\mathrm{m}^{3}$ \\
\hline $\begin{array}{l}\text { The share of renewable } \\
\text { energies (solar, wind, nuclear } \\
\text { plants, hydroelectric) }\end{array}$ & $30 \%$ of electricity by 2050 & \multicolumn{2}{|c|}{$50 \%$ of electricity by 2050} \\
\hline District application & \multicolumn{2}{|c|}{ Gasification of Akmola and Karaganda region } & $\begin{array}{l}\text { Gasification Nur-Sultan, } \\
\text { Karaganda, Pavlodar and } \\
\text { Eastern regions }\end{array}$ \\
\hline \multicolumn{4}{|c|}{ The trajectory generation (installed capacity) } \\
\hline Coal generation & $\begin{array}{l}\text { Significant growth to } 2050 \\
\text { ( } 80 \% \text { from the current level) }\end{array}$ & $\begin{array}{l}\text { Moderate growth up } \\
\text { to } 2030 \text { ( } 40 \% \text { from } \\
\text { the current level) }\end{array}$ & $\begin{array}{l}\text { Saving up to } 2030 \text { at current } \\
\text { level, decrease after } 2030 \text { due } \\
\text { to the old capacity }\end{array}$ \\
\hline Gas generation & $\begin{array}{l}\text { The transfer of CHP in major } \\
\text { cities for gas and the } \\
\text { commissioning of new } \\
\text { capacities for balancing } \\
\text { renewable energy }\end{array}$ & $\begin{array}{l}\text { Similarly, the } \\
\text { baseline scenario }\end{array}$ & $\begin{array}{l}\text { Similar to the baseline } \\
\text { scenario, as well as the } \\
\text { replacement of coal-fired plants } \\
\text { after } 2030\end{array}$ \\
\hline Nuclear power plant & $\begin{array}{l}\text { The construction of the } 1.5 \mathrm{GW} \\
\text { by } 2030 \text { and } 2 \mathrm{GW} \text { by } 2050\end{array}$ & - & - \\
\hline Renewable energies & $\begin{array}{l}\text { The commissioning of } 4.6 \mathrm{GW} \\
\text { wind farm, and } 0.5 \mathrm{GW} \text { of SES } \\
\text { by } 2030\end{array}$ & - & - \\
\hline
\end{tabular}

- There are two options for the development of new types of generation: the first - when the share of alternative and renewable energy sources in 2050 range from $30 \%$ (partial achievement of the objectives), the second $-50 \%$ (full achievement of the objectives of the Strategy - 2050) [7, 8];

- The maximum lifetime extension of existing coal, gas and hydro power stations. This solution is able to provide the lowest cost of electricity, so it is assumed the installation of powder-gas purification equipment as part of the modernization of existing coal plants to improve air quality and environmental standards;

- Forecast data on installed capacity in 2030 should amount 4.6 GW for wind power stations and $0.5 \mathrm{GW}$ for solar $[9,10,11]$;

- The construction of nuclear power plants is carried out in accordance with national plans. The total installed capacity of nuclear power is $1.5 \mathrm{GW}$ in 2030 and 2.0 GW in 2050 [12].

- Thermal power station (TPS) in all major cities of gasified regions are transferred from coal to gas to improve air quality [13].

It is possible to implement three scenarios of development of power industry, the characteristics of which are presented in table 1 [1].

As can be seen from figure 3 , despite a significant

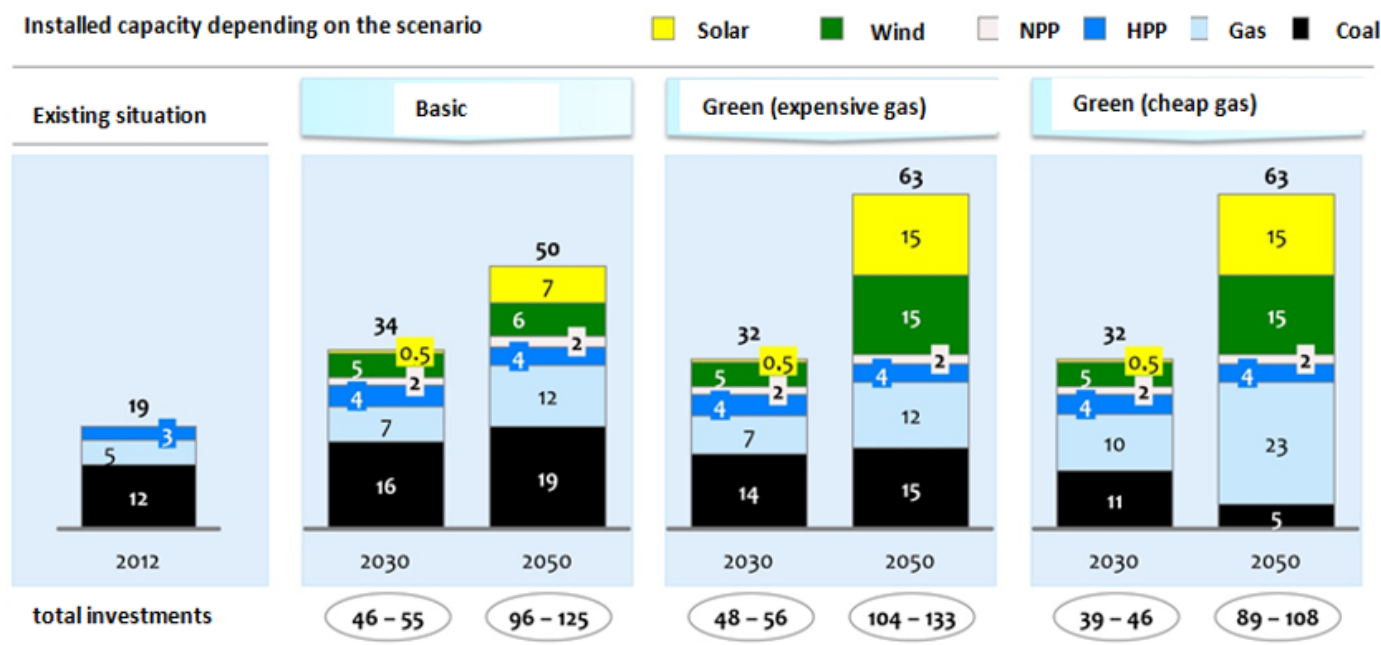

Fig. 3. The total installed capacity by scenario. 


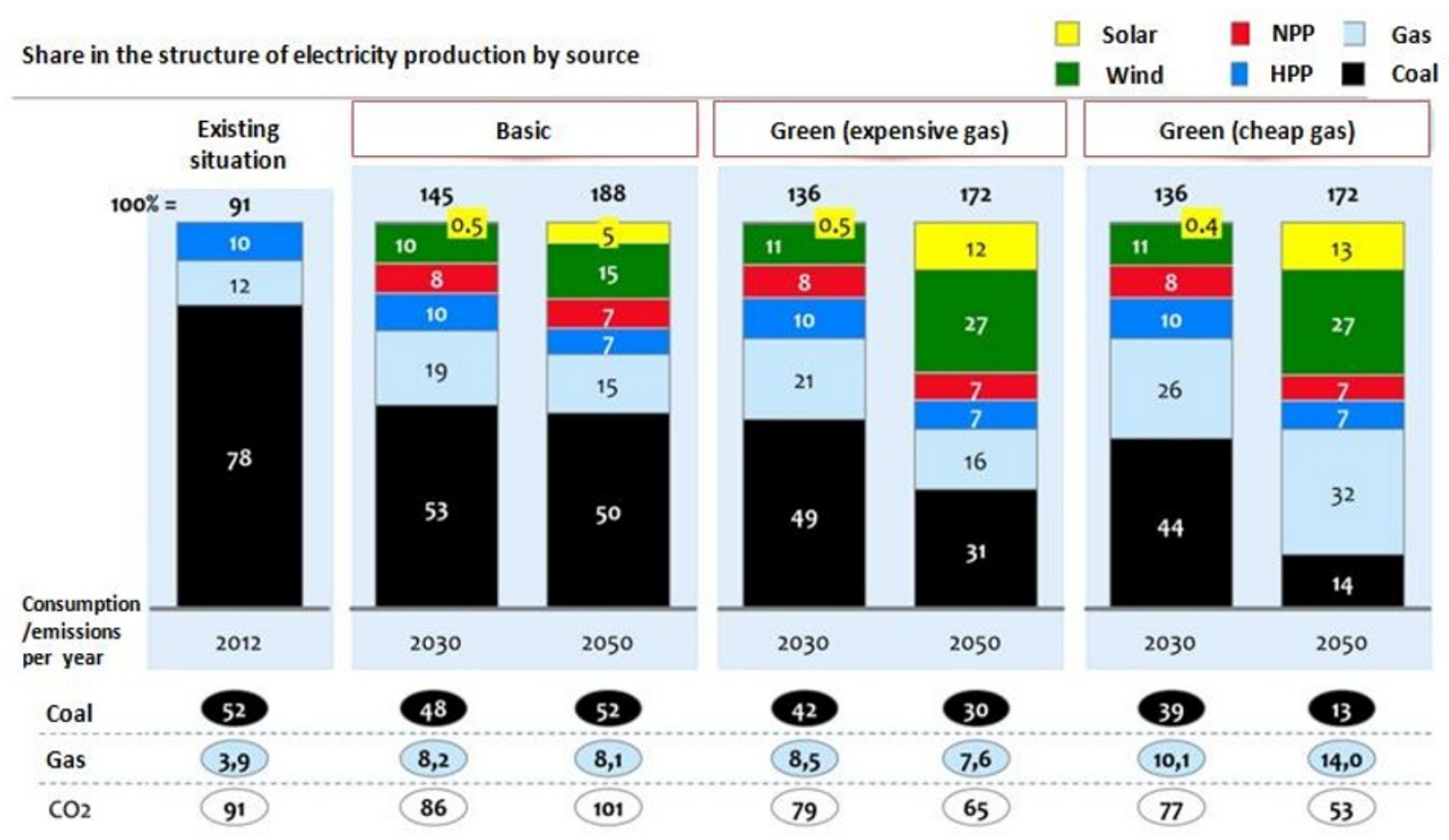

Fig. 4. The share of electricity production by scenario.

share of renewable energy sources (RES) by 2050 in the green scenarios, the total investment is similar to the baseline scenario due to lower capital costs for renewables. Presents the cumulative investments include investments in energy efficiency, modernization of existing facilities, installation of gas treatment, the construction of new facilities and infrastructure.

Analysis of the main simulation results shows that, despite the differences, most key indicators are comparable up to 2030 . In accordance with figure 4 , the expected volume of electricity production by scenario.

\section{Results}

Results of the presented data we can draw the following conclusions [1]:

- It is expected that the average cost of electricity production will increase by approximately double by 2030 and triple by 2050 compared to 2012 levels (in real terms), reaching $7-9 \mathrm{~m} / \mathrm{kWh}$ in 2030 and $10-14$ tenge/kWh in 2050.

- The total investment, including measures to increase energy efficiency, modernization, powder-gas purification equipment, construction of new facilities and infrastructure will be $40-55$ billion USD by 2030 and $90-130$ billion USD by 2050 depending on the scenario and the evolution of technologies for the production of electricity.

- The volume of electricity produced by coal stations, will remain approximately at current levels until 2030 in all scenarios: $60-75 \mathrm{TWh}$ in 2030, compared to $70 \mathrm{TWh}$ in 2012. The volume of annual coal consumption in the energy sector significantly reduced to 40-50 million tons in 2030 compared to 2012 levels - more than 50 million tons, mainly due to the increase in the efficiency of upgraded and new coal-fired power plants.

- The use of gas for electricity generation will double compared to current consumption and will reach 8 billion $\mathrm{m}^{3}$ per year in $2030\left(10\right.$ billion $\mathrm{m}^{3}$ per year in the green gas scenario) compared to about 4 billion $\mathrm{m}^{3}$ in 2012.

- The share of nuclear energy in all scenarios will be approximately $7-8 \%$ of the total volume of electricity produced as in 2030 and in 2050.

- Despite a two-fold increase in the production of electricity, $\mathrm{CO}_{2}$ emissions will slightly decrease from today's 90 million tonnes per year up to $75-85$ million tons per year by 2030, mainly due to the development of nuclear, alternative energy and increase the share of gas in the electricity production.

To date, the energy intensity of Kazakhstan's economy, which is dependent on trends in GDP and energy consumption patterns, twice the average level of OECD countries and 12\% higher than in Russia.

According to the International Monetary Fund it is expected that Kazakhstan's GDP will increase substantially (fivefold by 2050). Industry, housing and utilities, energy and transport will remain the leading sectors in terms of energy consumption. This assumes the reduction of energy intensity of GDP $25 \%$ by 2030 and $40 \%$ by 2050 relative to the current level through innovative technologies, use of alternative energy sources and energy conservation. The cost of energy saved according to calculations of the international experts will exceed the cost of entering new sources.

It is also assumed that energy efficiency improvements in major energy-consuming sectors of the economy to the level of European countries will 
significantly reduce the amount of energy used (33-43 million tons of oil equivalent) and capital costs [13].

For the growth of the efficiency of the economy it is necessary to develop a rational system of tariff and energy pricing, to develop local production of energyefficient building materials, to ensure optimum access to funding and the introduction of international energy management standards, to improve the legal mechanisms of production, consumption and conservation of energy. Great prospects for energy efficiency will provide replacement of the existing heat supply systems by reducing losses in heat energy transmission, upgrade of industrial equipment, repair of buildings to improve their energy efficiency, the development of transportation infrastructure. These measures are reflected in figure 5.

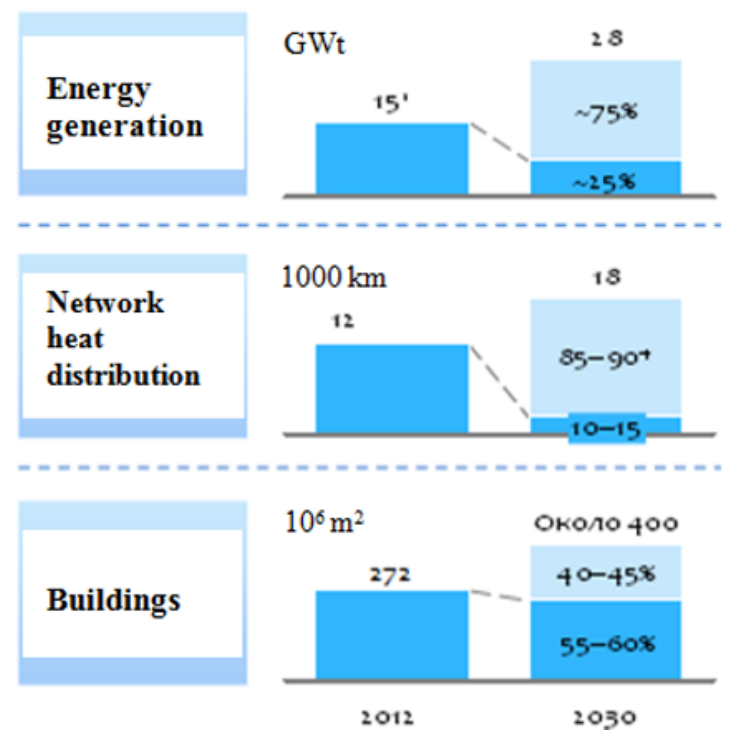

Fig. 5. Replacement infrastructure in the energy sector, 20122030 years, base scenario [3].

Additionally, the decrease in energy consumption means reducing emissions of $\mathrm{CO}_{2}$ and other pollutants.

It should be also improving of road infrastructure, increase the quality of production in refineries and the observance of quality standards in the segment of fuel retailing, the creation of incentives and conditions for the implementation of electric vehicles, the transition of wide layers of the population to Cycling and public transport, development of pedestrian routes health.

To improve the efficiency of the State program funding in the form of loans, tax breaks, interest rate subsidies, public-private partnerships to ensure sustainable accelerated industrial development.

It is possible to identify 3 facts about the transition to a green economy:

1. Positive results for the community $-2 / 3$ of investments are repaid from the point of view of the government, even if not to take into account additional (external) costs; $1 / 3$ of the investment reaching breakeven in less than 5 years.

2. High return on investment private investors - 33$50 \%$ of the necessary investment can be attracted as soon as possible; the return on investment in measures to improve energy efficiency is about $50 \%$, payback period
- 2 years; higher rates on the securities market, effectively using resources, outperformed competitors in the stock market by more than $55 \%$.

3. Investment in the green economy. It is easier to Finance investments in green growth, the fastest growing asset class, for example international investments in renewable energy are close to the same amount to investment in fossil fuels; investments in efficient use of resources and the development of "green" energy make up roughly $20 \%$ of the total multilateral funding.

For the purposes of implementation of the Concept on transition of Kazakhstan to "green economy" the Government has developed an action Plan [14], which provides measures for the implementation of innovative actions in the field of energy efficiency, access to sources of financing, modernization of existing enterprises through the formation of incentives and establishment of optimal tariffs, the regeneration and harmonization of the current legislation.

The whole idea of the Nur-Sultan (Astana) initiative have launched the trend of development of innovative economy and the prospects of ecologization of all spheres of society, which is reflected in the Concept of transition to green economy and its implementation Plan in Kazakhstan until 2050.

Implementation of the strategy of sustainable energy is a catalyst for wide social and economic development, it should provide a higher quality of life, the transition of society to new technological way is environmentally friendly environment.

\section{Discussion}

Sustainable energy of Kazakhstan is socially justified; gradually transforms energy in the form of system activities, inscribed in the socio-economic development; is the realm of mass application of high technologies; to gradually lead to systemic restructuring of primary energy sources as the way: on the one hand, providing the production the opportunity to have a guaranteed stream of energy, on the other - allowing you to have enough energy for the recycling of all production wastes and consumption; it is one of the important components of the national culture development.

Sustainable energy strategy should ensure the full implementation of the objectives "Sustainable energy for all", which is as follows: ensuring universal access to modern energy services; doubling the global rate of energy efficiency; doubling the share of renewable energy in the global energy balance.

In the framework of the "Sustainable energy for all" Kazakhstan follows the way of transition to "green economy".

The main objectives of the transition to a green economy are: improving the efficiency of resource use and management; modernization of existing and construction of new infrastructure; improving the wellbeing of the population and environmental quality through cost-effective ways to mitigate the pressure on the environment; increasing national security, including water security. 
In the context of development of "green economy" participants of economic relations show some willingness to pay more for "green" logistics solutions. Consumer demand is growing, so in the framework of creating sustainable and energy efficient future is necessary to provide a mass transition to a cleaner supply.

In the context of globalization and accession to the World Trade Organization (WTO) is of paramount importance in modern approaches to maintenance processes of exchange of goods, one of which acts as such an innovative approach as "green" logistics.

\section{References}

[1] The concept of transition of Kazakhstan to "green economy" 577 on May 30, 2013

[2] Global forecast "Future of civilizations" for the period up to 2050. Part 9. The future of civilizations and strategy of civilizational partnership. M.: MISK, 2009 (www.globlfuture.newparadigm.ru)

[3] Global forecast "Future of civilizations" for the period up to 2050. Part 3. Energy-ecological future of civilizations (Moscow: MISK) www.globlfuture.newparadigm.ru (2008)

[4] Article "More than a third of the planned 2015 new capacity put into operation in Kazakhstan MINT" from $9.10 .2013 \quad \mathrm{y}$., http:/www.newskaz.ru/economy/20131009/5643351.ht $\mathrm{ml}(2$ (The United Nations Millennium Declaration, General Assembly resolution 55/2 of 8 September 2000 (Millennium development Goals)

[5] N.A. Nazarbayev, Strategy for global energy and environmental sustainable development in the twenty-first century (Astana: Economy) (2011)

[6] Y.V. Yakovets, Energy-ecological future of Eurasian civilization: saving strategy (Bulletin of the Kazakh national Academy of natural Sciences) 2, (2014)

[7] The Message of the President of the Republic of Kazakhstan "Strategy - 2050"

[8] News of electric power industry. A breakthrough in the country's energy sustainability. Source: website of the state energy supervision, http://www.kea.kz/readNews.php?did=749

[9] Fundamentals of a long-term strategy for global sustainable development based on the partnership of civilizations (Moscow: MISK) www.globlfuture.newparadigm.ru 2011

[10] Scientific basis for strategy to overcome the crisis of civilization and achieve a trajectory of global sustainable development (Moscow: MISK) 2013

[11] N.A. Nazarbayev, The strategy of radical renewal of the global community and the partnership of civilizations. Astana (2011)

[12] Social and economic development of the CIS countries in 2013 (Moscow: CIS Status Committee) (2014)

[13] Presentation of the Innovation Park of the Eurasian National University "Implementation of the energy management system in ENU. A pilot project
"Translation of boiler of ENU from the diesel fuel alternative February 27, 2012

[14] The article "the Astana Initiative "Green bridge" - start the transition to a green economy", the Newspaper "Ecology of Kazakhstan" №3 (022), October (2013) 